\title{
Statistical and Financial Analysis of Georgian Railway`s Main Performance Indicators in 2006-2019
}

\author{
Davit Gondauri $^{1}$ \& Manana Moistsrapishvili ${ }^{2}$ \\ ${ }^{1}$ Business and Technology University, Tbilisi, Georgia \\ ${ }^{2}$ Georgian Technical University, Tbilisi, Georgia \\ Correspondence: Davit Gondauri, Business and Technology University, I. Chavchavadze Avenue N82, Tbilisi \\ 0162, Georgia.
}

Received: July 16, 2019

Accepted: August 30, 2019

Online Published: September 16, 2019

doi:10.5539/ibr.v12n10p64

URL: https://doi.org/10.5539/ibr.v12n10p64

\begin{abstract}
Due to the geopolitical location, Georgia can become the center for Caucasus transport-logistics; partly it still performs this function. The purpose of this research paper is to study and analyze the financial-economic and statistical position of the main indicators of the Georgian Railway Holding. Based on all the above mentioned, we have set out the tasks of the research: Statistic analysis of the value added created by the Railway Industry in the Georgian economy years 2006-2019, Determination of correlation between the general indicators of JSC "Georgian Railway" and factors operating on it, Comparative analysis of the financial indicators of the Georgian railway in the post soviet space. Data was taken from the Georgian Railway Information Technology Agency. We observed the sensitivity of cargo movement in the region. The correlation between the general indicators of JSC "Georgian Railway" and its operating factors are also reflected in the study. Despite the small portion of the railway in the country's GDP, its role in the socio-economic development of the country is great. The average annual geometric growth of the EBITDA of regionals railways is decreasing. This reduction is caused by general economic shocks in region and slowing of economic growth. However, it is worth mentioning that the results of Georgian Railway compared with the other countries are only $4 \%$ reduction. This means that the reduction of shipping of oil and dry cargo by the Georgian Railways in recent times is caused by external factors.
\end{abstract}

Keywords: CAGR, slope coefficient, pearson correlation, railway financial statements, railway cargo transportation, railway EBITDA margin, Georgian GDP

\section{Introduction}

Railway industry is an important part of Georgian economy. Its strategic location near the Black Sea and the fact that Georgia is a marine gateway for the Transcaucasian region defines its geopolitical advantage and requires proper appreciation and application (Putkaradze B., 2013). Due to the geopolitical location, Georgia can become the center for Caucasus transport-logistics; partly it still performs this function (Putkaradze B., 2013). The idea of the Trans-Asian Railway, which connects the Asian continent with Europe, still emerged in the 1950s. However, the full operation of this mega project, the multilateral rail corridors (north, south, southeast, north-south), has been hampered by decades of various geopolitical or regional disagreements as well as different dimensions of the railway track (Tsuladze, 2015).

Difficulty in organizing shipping except for natural factors (additional loading and unloading operations on the Caspian and Black Seas), which is reflected in the overheads, it also depends on the transport market subjects (railroads, shipping lines, port operators, terminators, shippers, terminals owners, shippers) Sports Policy (Tsagareishvili \& Svanidze, 2009). The Caspian Sea rail ferry links Kazakhstan and Turkmenistan with Azerbaijan for the purpose of cargo fall through Azerbaijan, Georgia and Turkey to European railways and ports. The annual throughput of the Caspian Railways is 95,000 freight wagons or 4.5 million tonnes. The average annual load of a railway ferry is currently half or sometimes up to $70 \%$ of its capacity (Tarimanashvili, 2017).

The necessity of the development of the Georgian sea ports is preconditioned by the increase of cargo flow in the Trans-Caucasus and middle Asia states (Diasamidze, 2016). Maritime transport is crucial in the world transport system and international economic relations are impossible without such transport (Nakashidze, 2016). Open Society Georgia Foundation (OSGF) in his report Georgian Railway (Problems and Perspectives) has analyzed 
the transit function of Georgian Railway and its transit potential. The authors emphasize the main importance of the Georgian Railway, which is clarified by the following characteristics: (1) The Georgian railway connects the Caspian and Central Asian region to Europe with the alternative roat; (2) Georgia owns the Ports and terminals with the strategic locations (Poti, Batumi and Kulevi) which are directly linked to the railway lines of Azerbaijan, Ukraine, Bulgaria and Russia; (3) After the implementation of the new project "Baku-Tbilisi-Kars Railway", Georgia will also connect to Turkish railway line (Lashkhi, I. et al, 2008).

"Standart \& Poor's" comprehensive analysis of the Georgian Railway, points out the key factor in Georgia's ranking rating. Strength are a monopolistic position as a vertically integrated railway carrier in the Europe-Caucasus-Asian transport corridor, relatively high operating share in relation with the correct management team, very high probability of government support. However, weakneses are over-reliance on transit freight revenues and an important capital spending program in 2012-2014 (Binder, T., et al, 2010).

It is necessary for the railway to be able to offer beneficial conditions for its customers and their practical implementation. This requires a robust infrastructure that ensures cargo protection, fast shipping and reduced transportation costs (Japaridze, 2012). Given the environmental conditions, the question arises as to whether Georgia's rail transport is ready to be integrated into the international corridor based on infrastructure and economic indicators (Sidamonidze, 2018). According to the assessment of Booz Allen Hamilton [BAH] infrastructure of the Georgian railway consists of several components: bridges, tunnels, trunk-railway, communication means, power supply, depots, stations, and related equipment (BAH, 2005). However, only the central strip of the Georgian territory looks relatively complete with the railway lines and the appropriate technical equipment (Telia, 2016).

Calculations are provided regarding the share of the Railway System in the country's Gross domestic product (GDP) in period of 2006-2017 year and the Compound annual growth rate (CAGR) of cargo volumes in 16 years' cycle allowing the JSC „Georgian Railway“ to create the additional value in the country's overall GDP. In this study indicate that the additional value to GDP is the direct and indirect form of development and growth of various sectors of the economy of Georgia, as some part of the cargo shipped in the railway remains in Georgia and is used in the process of production, which in itself adds value added to the economic growth of the country. Rates are a simulation of the regression model which gives the result of the Economic value added (EVA) that creates the railway GDP with the CAGR model of cargo growth. Therefore, the interest rate mentioned in the regressive model is adopted by the following mathematical formula: (Railway Present Value of EVA) / (Present Value of Future Value of GDP) (Gondauri, D., \& Moistsrapashvili, M., 2019).

Nowadays it is very important to identify and study the weaknesses of the orientation scale on business in the Georgian Railway, which is resulted due to the following factors:

$>$ Absence of the strategy fpor attracting additional cargo;

$>$ Old railway infrastructure;

JSC "Georgian Railway" as a business subject for investors with less attractive conditions;

$>$ Low level of human Resource skills.

The purpose of this research paper is to study and analyze the financial-economic and statistical position of the main indicators of the Georgian Railway Holding.

Based on all the above mentioned, we have set out the tasks of the research:

- Statistic analysis - Slope of the value added created by the Railway Industry in the Georgian economy in 2006-2019;

- Determination of correlation between the general indicators of JSC "Georgian Railway" and factors operating on it;

- Comparative analysis of the financial indicators of the Georgian railway in the post soviet space;

\section{Review of the Literature. A Brief Overview of Various Railways}

Statistics are the arithmetic of welfare. It is only through the acquisition of accurate statistical data that the govt. can successfully implement its plans on the operational and administrative sides that they help in the solution of complicated problems. They are of great importance for exercising proper managerial control and formulation of policy in a big undertaking like Indian Railways. Their timely availability is of crucial importance when major decisions involving crores of rupees and affecting millions of people have to be made (Indian Railway, 2012). 
Total government support to the rail industry is the level of funding government provides towards operating, maintaining, renewing and enhancing the railway. It shows grants to domestic passenger operators and Network Rail and covers the following categories: Central government grants; Passenger Transport Executive grants; Direct rail support; Other elements of government support; Loans issued to Network Rail and freight grants are presented separately. Franchising decisions taken by government can also affect private investment (Office of Rail and Road, 2018).

The positive development that the German economy has seen since the crisis in 2009 continued through the year 2017 when Germany's real gross domestic product grew by 2.2 percent over 2016 . After having fallen by 0.5 percentage points in 2015, GDP growth has remained constant since 2016. Looking at the modal split in 2017, the share of rail freight transport increased by 0.1 percent, while the share held by inland waterway transport remained stable at 8.4 percent. The share of road freight transport correspondingly declined by 0.1 percent. The share held by inland waterway transport has steadily declined since 2014. The railway market is divided into the transport market and the infrastructure market. Railway undertakings provide rail transport services. The Bundesnetzagentur monitors the railway undertakings operating in Germany; it determines how well the railway market functions and how efficient it is (Bundesnetzagentur, 2018).

The fair values of financial instruments include market prices or reasonably estimated values if there are no market prices. Because estimation of fair values incorporates variable factors, adopting different assumptions can change the values (East Japan Railway Company, 2017).

The consolidated entity's activities expose it to a variety of financial risks including market risk, credit risk and liquidity risk. All cash and cash equivalents, derivative financial instruments and borrowings are held and recognised by Queensland Rail Limited. The Queensland Rail parent entity is not exposed to any market, credit or liquidity risk within the consolidated entity. The fair value of financial assets and financial liabilities must be estimated for recognition and for disclosure purposes. The derivative financial assets and liabilities held by the consolidated entity have been classified as level 2 on the fair value hierarchy as values are indirectly derived from market indices (Queensland Rail, 2018).

The strategic role that railways once played in the development of the Canadian economy has dwindled over time as other modes of transport have developed and governments have withdrawn or reduced their support for uneconomical railway lines. Cash strapped railways, also faced with the problem of excess capacity, have endeavoured to rationalise their lines. The National Transportation Act, 1987 provided for rationalisation but the process was slow because of certain restrictions on abandonment and/or transfer of lines. The new Canada Transportation Act, enacted July 1996, has facilitated the process of abandonment and acquisition of surplus lines by short line railways (Statistics Canada, 1999).

\section{Research Methods}

\subsection{Overview of Research Methods}

In the process of the analyses of the actual materials and the tasks set out in the article uses the empirical data systematization, verbal discussion of their results, conclusions and general regularities of the relationship between the formal - logical description, statistical research methods, classification methods, system approach, forecasting, statistical data monitoring, comparative analysis, generalization and systematization methods.

Data was taken from the Georgian Railway Information Technology Agency. We observed the sensitivity of cargo movement in the region. Systematization and comparison of data from Information Technologies Service of various Railways. From the statistical research methods, we have chosen to analyze the regression model. Classification of cargo shipments in the region according to their categories. In the study with regressive analysis, including the slopes model, based on which we found out what percentage change was required to increase the value added by the railway in GDP growth of 1 percent. We have identified the correlation between the Railway industry and GDP, identified the determinant of the connection $\left(\mathrm{R}^{2}\right)$. The correlation between the general indicators of JSC "Georgian Railway" and its operating factors are also reflected in the study. Comparative analysis of the financial indicators of the Georgian Railway is analyzed in respect of other railways operating in the post-Soviet Countries. The study also highlights the financial-economic indicators of JSC "Georgian Railway".

During the implementation of the research we have used the methods of regressive analysis. Together with the mathematical approaches to correlate density, we have formulated the general equation of the railway Silk Road effectiveness. It is based on factor analysis based on the methods of extrapolation, for which various mathematical and economic methods are used. CAGR is one of the most accurate ways to calculate the return on 
an investment that rises and falls in value during the investment period. CAGR allows investors to compare investments with different time horizons. CAGR makes it possible to compare profits from a particular investment with risk-free instruments. It also allows you to assess whether the premium for the risk taken is high enough.

The compound annual growth rate (CAGR) is the rate of return that would be required for an investment to grow from its beginning balance to its ending balance, assuming the profits were reinvested at the end of each year of the investment's lifespan.

\subsection{Slope of Regression Line}

The slope of a regression line $(b)$ represents the rate of change in $y$ as $x$ changes. Because $y$ is dependent on $x$, the slope describes the predicted values of $y$ given $x$. When using the ordinary least squares method, one of the most common linear regressions, slope, is found by calculating $b$ as the covariance of $x$ and $y$, divided by the sum of squares (variance) of $x$,

$$
\frac{\sum_{i=1}^{n}\left(x_{i}-\bar{x}\right)\left(y_{i}-\bar{y}\right)}{\sum_{i=1}^{n}\left(x_{i}-\bar{x}\right)^{2}} .
$$

The slope must be calculated before the $y$-intercept when using a linear regression, as the intercept is calculated using the slope. The slope of a regression line is used with a t-statistic to test the significance of a linear relationship between $x$ and $y$ (Bewick, V., Cheek, L., \& Ball, J., 2003).

\subsection{Volume speed of the shipped cargo}

The volume speed of the cargo shipped with the railway transport may be shown as the function of the mathematical model (y), and the factors acting on it in the table can be obtained as arguments (xi); as a result we have the mathematical model where:

$$
y=f(x i)
$$

\section{Where: $y$-ecuals function, $x i$-any I argument}

\subsection{Pearson correlation coefficient}

By examining the Pearson's correlation coefficients and regression analysis, it is possible to identify key factors affecting the main technical and economic parameters in transport enterprises (Kurtanidze, 2012).

There are several methods of calculating the correlation coefficient. In the given case we use the so-called Correlation coefficient of Peareson. In this case the correlation coefficient (R) between two $x$ and $y$ values (Rxy) is calculated using the formula:

$$
r=\frac{\sum(x-\bar{x})(y-\bar{y})}{\sqrt{\sum(x-\bar{x})^{2} \sum(y-\bar{y})^{2}}}
$$

where $\mathrm{x}$ and $\mathrm{y}$ (stroke) values represent the dispersion medium.

In order to calculate the correlation coefficient by this formula, we should introduce indications:

$\mathrm{y}$ - Volume of shipped cargo in thsousand tones;

$\mathrm{x} 1$ - Local transportation;

x2 - Import;

x3 - Export;

x4 - Transit;

x5 - Oil and oil products;

x6 - crude oil;

x7 - Dry cargoes; 
x8 - Aluminum oxide

x9 - bauxite;

x10 - black metals;

x11 - Black metal scrap;

$\mathrm{x} 12$ - Industrial raw materials;

x13 - construction materials;

x14 - Wheat and wheat products;

x15 - Sugar;

x16 - Freight Turnover;

x17 - Revenue from shipping;

x18 - Domestic

x19 - Import;

x20 - Export;

$\mathrm{x} 21$ - Transit;

$\mathrm{y}$ - and $\mathrm{x} 1$ correlation coefficient can be marked as R1, y-and $\mathrm{x} 2$ correlation coefficient R2 ans so on (Bewick, V., Cheek, L., \& Ball, J., 2003).

\section{Research Results}

4.1 Statistical analysis - Slope of the value added by the railway industry in the Georgian economy in 2006-2019 Despite the small portion of the railway in the country's GDP, its role in the socio-economic development of the country is great.

Table 1. The share of the railway system in the country's GDP

\begin{tabular}{|c|c|c|c|}
\hline Year & Railway Transport & GDP market prices & \% from total GDP \\
\hline $\mathbf{2 0 0 6}$ & 65.6 & 13,790 & $0.48 \%$ \\
\hline $\mathbf{2 0 0 7}$ & 57.5 & 16,994 & $0.34 \%$ \\
\hline $\mathbf{2 0 0 8}$ & 54 & 19,075 & $0.28 \%$ \\
\hline $\mathbf{2 0 0 9}$ & 49 & 17,986 & $0.27 \%$ \\
\hline $\mathbf{2 0 1 0}$ & 62.9 & 20,743 & $0.30 \%$ \\
\hline $\mathbf{2 0 1 1}$ & 71.1 & 24,344 & $0.29 \%$ \\
\hline $\mathbf{2 0 1 2}$ & 70.2 & 26,167 & $0.27 \%$ \\
\hline $\mathbf{2 0 1 3}$ & 70.1 & 26,847 & $0.26 \%$ \\
\hline $\mathbf{2 0 1 4}$ & 71 & 29,150 & $0.24 \%$ \\
\hline $\mathbf{2 0 1 5}$ & 76.2 & 31,756 & $0.24 \%$ \\
\hline $\mathbf{2 0 1 6}$ & 59 & 34,028 & $0.17 \%$ \\
\hline $\mathbf{2 0 1 7}$ & 55 & 37,847 & $0.15 \%$ \\
\hline
\end{tabular}

Source: National statistics office of Georgia. Gross Domestic Product at current prices by 45 activities http://www.geostat.ge/index.php?action=page\&p_id=119\&lang=eng

The table 1 presented above shows that in the period 2006-2017 the GDP volume created in the railway sector is characterized by decreasing trend, which is due to the correlation of external and internal Economical shocks on the railway transport.

Table 2. Statistical analysis of the value added by the railway industry in the Georgian economy in 2006-2019

\begin{tabular}{lc}
\hline \multicolumn{1}{c}{ Statistical analysis of the value added by the railway industry in the Georgian economy in 2006-2019 } \\
\hline Maximum share & $0.551 \%$ \\
Minimum share & $0.131 \%$ \\
Average & $0.264 \%$ \\
Standard deviation & $0.090 \%$ \\
SLOPE & $47.633 \%$ \\
Correlation & $14.544 \%$ \\
\hline
\end{tabular}


- The table 2 below analyzes the share of the railway in GDP from 2006 to the first quarter of 2019. In this case the railways had the maximum share of $0,55 \%$ in the first quarter of 2006, and in the fourth quarter of the 2018 - $0,131 \%$. In the first quarter of 2019 , the indicator amounted to $0.155 \%$. The standard deviation of this indicator in 2006-2019 amounted to 0,0896\%, which shows low sensitivity of the variable;

- The Slope of the Railway and GDP logarithms was calculated and the resulted amount is $47.63 \%$. This means that in order to increase GDP by 1 percent in 2006-2019, it was necessary to increase the value added by the railway up to $47.63 \%$. As for the correlative relation of the railway with the GDP - is $14,555 \%$, and its determination $\left(\mathrm{R}^{2}\right)$ - represents $2,12 \%$.

4.2 Determining Correlative Relations Between Generalized Indicators of JSC "Georgian Railway" and the Factors Affecting Them

The efficiency of management of transport enterprises is significantly dependent on the volume of freight transportation, since it is directly related to the company's revenue and the volumes of the reporting and accounting models. The volume of the freight transported by JSC "Georgian Railway" is given in Table 3. (According to the years).

Table 3. The volume of the freight transported by JSC "Georgian Railway" (2003-2018)

\begin{tabular}{|c|c|c|c|c|c|c|c|c|c|c|c|c|c|c|c|}
\hline 2003 & 2004 & 2005 & 2006 & 2007 & 2008 & 2009 & 2010 & 2011 & 2012 & 2013 & 2014 & 2015 & 2016 & 2017 & 2018 \\
\hline 16,559 & 15,424 & 18,987 & 22,643 & 22,231 & 21,181 & 17,104 & 19,930 & 20,123 & 20,076 & 18,185 & 16,673 & 14,143 & 11,882 & 10,673 & 10,005 \\
\hline
\end{tabular}

Source: Georgian Railway Information Technology Agency

The volume of the cargo is affect by almost every aspect of internal and external management. Statistical materials of JSC "Georgian Railway" are used for calculations such as: volume of local transportation, volume of goods imported, number of passenger transfers, and number of suburban and local transfers, volume of revenue from local as well as total transportation, pasanger transportation and more. The numerical value of the some indicators considered as factors in the volume of transported cargoes are shown in Table 3.

Between the Function and arguments, as in the most economic indicators, there is no definitive or strictly established precise links. Such connections usually have statistical (probabilistic) character. In the theory of statistics for determining the level of connection so called Correlation coefficient is used, meaning connections can be a correlative.

The calculations gave us the following results in Table 4.

Table 4. Correlation of main indicators of Georgian Railway operation with the volume of freight transported between the years 2003-2018

\begin{tabular}{|c|c|c|c|}
\hline \multicolumn{4}{|c|}{$\begin{array}{l}\text { Correlation of main indicators of Georgian Railway operation with the volume of freight transported between the } \\
\text { years 2003-2018 }\end{array}$} \\
\hline 1 & Local & $\mathrm{R} 1$ & $66.44 \%$ \\
\hline 2 & Import & $\mathrm{R} 2$ & $30.76 \%$ \\
\hline 3 & Export & R3 & $52.57 \%$ \\
\hline 4 & Transit & $\mathrm{R} 4$ & $96.50 \%$ \\
\hline 5 & Oil and oil products & R5 & $93.07 \%$ \\
\hline 6 & Crude oil & R6 & $87.85 \%$ \\
\hline 7 & Dry cargo & R7 & $78.55 \%$ \\
\hline 8 & Aluminum oxide & R8 & $85.48 \%$ \\
\hline 9 & Bauxite & R9 & $56.27 \%$ \\
\hline 10 & Black metals & $\mathrm{R} 10$ & $5.23 \%$ \\
\hline 11 & Black metal scrap & R11 & $47.98 \%$ \\
\hline 12 & Industrial raw materials & R12 & $54.04 \%$ \\
\hline 13 & Construction material & $\mathrm{R} 13$ & $39.27 \%$ \\
\hline 14 & Wheat and wheat products & $\mathrm{R} 14$ & $80.55 \%$ \\
\hline 15 & Sugar & $\mathrm{R} 15$ & $77.66 \%$ \\
\hline 16 & Income from transportation & $\mathrm{R} 16$ & $-0.08 \%$ \\
\hline 17 & Local & $\mathrm{R} 17$ & $-13.36 \%$ \\
\hline 18 & Import & $\mathrm{R} 18$ & $-53.36 \%$ \\
\hline 19 & Export & $\mathrm{R} 19$ & $-41.28 \%$ \\
\hline 20 & Transit & $\mathrm{R} 20$ & $23.57 \%$ \\
\hline
\end{tabular}


In statistical calculations, if the absolute value of the correlation coefficient exceeds 0,5 , then there is a correlative relation, which means that the influence of the argument for the function is important. If the absolute value of the coefficient is less than 0,5 the connection between the argument and the function is insignificant and the subsequent calculations do not take into account such factors. In our case there is a close correlation between the turnover and the volume of freight transported (R4=96,50\%) which corresponds to the overall economic performance. However, as the calculations show, the correlation of some of the railway indicators is less than 0,5 in volume of transported freight and some are even negative.

\subsection{Comparative Analysis of the Financial Indicators of the Georgian Railway in the Post-Soviet Countries}

In comparison with region's other railway indicators, Georgian Railways earnings before interest, taxes, depreciation, and amortization (EBITDA) margin in years 2010-2016 is the highest. Whiching that the decisions made by the company's management are proper and resulted in correct business processes.

Table 5. Comparison with other railway indicators, Georgian Railways EBITDA margin in years 2010-2016 is the highest

\begin{tabular}{cccccccc}
\hline EBITDA Margin\% & $\mathbf{2 0 1 0}$ & $\mathbf{2 0 1 1}$ & $\mathbf{2 0 1 2}$ & $\mathbf{2 0 1 3}$ & $\mathbf{2 0 1 4}$ & $\mathbf{2 0 1 5}$ & $\mathbf{2 0 1 6}$ \\
\hline Georgian Railway & 48.1 & 54.4 & 53.6 & 47.8 & 49.6 & 56.2 & 45.8 \\
Ukrainian Railway & 24.7 & 27 & 22.1 & 22.3 & 17.9 & 29.3 & 23.5 \\
Kazakhstan Railway & 29.2 & 33.4 & 32.2 & 34 & 30.6 & 22.3 & 25.1 \\
Russian Railway & 28.4 & 19.8 & 25.9 & 18.8 & 19.6 & 19.5 & 20.9 \\
\hline
\end{tabular}

Table 6. CAGR - EBITDA Average annual geometric growth (change in 2010-2016 years)

\begin{tabular}{lc}
\hline \multicolumn{1}{c}{ CAGR - EBITDA Average annual geometric growth (change in 2010-2016 years) } \\
\hline Georgian Railway & $-4.05 \%$ \\
Ukrainian Railway & $-11.80 \%$ \\
Kazakhstan Railway & $-10.20 \%$ \\
Russian Railway & $-10.10 \%$ \\
\hline
\end{tabular}

The presented table shows that the average annual geometric growth of the CAGR - EBITDA of all four railways is decreasing. This reduction is caused by general economic shocks in region and slowing of economic growth. However, it is worth mentioning that the results of Georgian Railway compared with the other countries are only $4 \%$ reduction. This means that the Georgian Railway has done better than the economic shocks of the region during this period.

Table 7. Average annual prices of Eurobond

\begin{tabular}{ccccc}
\hline \multicolumn{5}{c}{ Average annual prices of Eurobonds (USD) } \\
\hline Date & Georgian Railway & Ukrainian Railway & Kazakhstan Railway & Russian Railway \\
\hline 2017 & 110.29 & 101.92 & 108.24 & 107.67 \\
2016 & 108.11 & 93.2 & 0 & 104.35 \\
2015 & 105.46 & 0 & 0 & 93.12 \\
2014 & 109.71 & 0 & 0 & 96.9 \\
2013 & 110.43 & 0 & 0 & 105.9 \\
2012 & 109.08 & 0 & 0 & 108.68 \\
\hline
\end{tabular}

The price of Georgian Railway Eurobonds in the financial market, compared with other railways is the region was the highest in 2012-2017. Ukraine and Kazakhstan have started their operations on the financial market in years 2016-2017. 
Table 8 . The region's railway credit ratings

\begin{tabular}{ccccc}
\hline & Ranking & Rating date & Forecast & \multicolumn{2}{c}{ the forecast granting } \\
date
\end{tabular}

The region's railway credit ratings (Fitch / S \& P / Moody's) (Azerbaijan Railway was removed by the ranking companies in year 2016).

Table 9. Financial and non-Financial Highlights

\begin{tabular}{llll}
\hline Financial and non-Financial Highlights & \multicolumn{3}{c}{} \\
\hline For the year (in GEL '000) & $\mathbf{2 0 1 8}$ & $\mathbf{2 0 1 7}$ & $\mathbf{2 0 1 6}$ \\
Revenues & 424,614 & 434,534 & 439,922 \\
EBITDA & 172,322 & 211,851 & 281,755 \\
Adjusted EBITDA & 156,846 & 181,425 & 195,149 \\
Earnings before interest and taxes (EBIT) & 58,518 & 102,148 & 175,488 \\
Net loss/income & $-716,539$ & $-354,100$ & 65,126 \\
Cash provided by operating activities & 179,040 & 176,232 & 187,411 \\
Acquisition of Property, plant and equipment (PPE) & 104,694 & 165,265 & 200,274 \\
At year end (in GEL' '000) & $\mathbf{2 0 1 8}$ & $\mathbf{2 0 1 7}$ & $\mathbf{2 0 1 6}$ \\
Total assets & $2,264,012$ & $2,862,237$ & $3,225,683$ \\
Total liabilities & $1,734,796$ & $1,617,389$ & $1,626,407$ \\
Total equity & 529,216 & $1,244,848$ & $1,599,276$ \\
Financial ratios & $\mathbf{2 0 1 8}$ & $\mathbf{2 0 1 7}$ & $\mathbf{2 0 1 6}$ \\
Revenue growth & -0.0228 & $-1.22 \%$ & $-23.46 \%$ \\
EBITDA margin & $40.60 \%$ & $48.75 \%$ & $64.05 \%$ \\
Adjusted EBITDA margin & $36.94 \%$ & $41.75 \%$ & $44.36 \%$ \\
Operating ratio & $89.94 \%$ & $85.46 \%$ & $82.71 \%$ \\
Dividend payout ratio & $0 \%$ & $0 \%$ & $0 \%$ \\
Interest coverage ratio & 0.62 & 0.99 & 1.91 \\
Net debt/EBITDA & 6.19 & 4.87 & 3.48 \\
Debt/Equity & 3.28 & 1.3 & 1.0 \\
Statistical data (in '000) & $\mathbf{2 0 1 8}$ & $\mathbf{2 0 1 7}$ & $\mathbf{2 0 1 6}$ \\
Tons & 10,005 & 10,673 & 11,882 \\
Ton-km & $2,571,108$ & $2,929,793$ & $3,390,880$ \\
Number of passengers & 2,851 & 2,684 & 2,463 \\
Passenger-km & 633,613 & 596,727 & 508,586 \\
Average number of employees & 13 & 13 & 13 \\
Key operating measures & $\mathbf{2 0 1 8}$ & $\mathbf{2 0 1 7}$ & $\mathbf{2 0 1 6}$ \\
Total freight revenue per ton-km (in Tetri) & 14.1 & 13.2 & 11.7 \\
Passenger revenue per passenger-km (in Tetri) & 4.3 & 3.8 & 3.5 \\
Revenue per average number of employees (in GEL '000) & 33.54 & 33.91 & 33.98 \\
Operating expenses per ton-km (in GEL) & 0.15 & 0.13 & 0.11 \\
Ton-km per average number of Freight SBU employees in '000 & 466.54 & 524.44 & 606.92 \\
Passenger -km per average number of Passenger SBU employees in '000 & 508.52 & 461.15 & 366.42 \\
Safety indicators & $\mathbf{2 0 1 8}$ & $\mathbf{2 0 1 7}$ & $\mathbf{2 0 1 6}$ \\
Accident rate per million ton-km & 0 & 0.04 & 5.02 \\
Injury per '000 number of average employees & 0 & 0 & 5.72 \\
Death per '000 number of average employees & 0 & 0.54 \\
\hline
\end{tabular}


The table 9 shows that EBITDA is calculated by adding back depreciation and amortization as well as impairment loss to the results from operating activities. Adjusted EBITDA is adjusted for significant non-cash and one-off items. Financial result variances at constant currency are obtained by converting the comparable period of the current-year results denominated into Georgian Lari at the average foreign exchange rates for the prior period. Its EBITDA margin and adjusted EBITDA margin are still on significant levels at 41 percent and 37 percent, respectively. The Group is of significant importance to the country, and its revenue represented about 1.1 percent of the country's total GDP in 2017 and 1.0 percent of the country's total GDP in 2018. The Group is one of the biggest taxpayers and largest corporate employers in the country. It is also considered to be a strategic partner in national and economic development as it facilitates development in other industrial sectors (locomotive construction, railcar repair, concrete sleeper production, etc.) and plays a critical role in maintaining strong economic relations between Georgia and its partner countries such as Azerbaijan, Armenia, Kazakhstan, Tajikistan, Turkey and Turkmenistan.

Table 10. Credit Ratings by the End of 2018

\begin{tabular}{ccccccccc}
\hline \multicolumn{10}{c}{ Credit Ratings by the End of 2018 } \\
\hline & First issued & LT & Outlook & ST & Last updated & LT & Outlook & ST \\
\hline Standard \& Poor's & 2010 & B+ & Stable & B & 2018 & B+ & Stable & B \\
Fitch Ratings & 2011 & B+ & Stable & B & 2019 & B+ & Positive & B \\
\hline
\end{tabular}

\section{Conclusion and Recommendations}

The reduction of the volume in the recent period in some oil and dry cargo transportation by the Georgia Railway was caused due to the following reasons:

1. In the neighboring countries, the oil and gas processing plants are gradually reconstructed, the reconstruction period began in early spring 2016, which was planed to complete gradually in 2017.

2. With low economic activity in the neighboring countries, specifically the reduction of the trade turnover in western-eastern region (where Georgia is playing the interlocking part). However, it should be noted that in some cases the internal economic activity of the regions has increased - trade turn over which does not include the trade and economic activity from west to east (Asian countries) and vice versa. This condition caused a decline in the transportation of dry cargo - such as construction materials. Simultaneously, due to the deterioration of natural and economic conditions in the Asian countries, the grain harvest was reduced which consequently caused the decrease in the transportation.

For the purpose of attracting the additional cargoes and to improve the financial and statistical indicators of the company, it is desirable to:

1. To initiate and lobby with the purpose of establishing a single tariff route for Georgia;

2. The necessity to set up terminals and hubs outside Georgia. Georgian Railway should not start in Poti or Batumi and end up in Gardabani. Today there is no problem of transporting the cargo, the task is to accumulate a cargo in one point, particular in terminals. (There should be terminals in Romania, Azerbaijan, Kazakhstan and in China);

3. Railway ownership should have marine facilities both in Caspian and Black Sea and the specific rolling stock;

4. Capital investments in trader and logistic companies are essential.

The task of the most recent years of JSC "Georgian Railway" is to urgently improve the industrial economic indicators of the enterprise, such as additional economic value.

In order to ensure that the Georgian Railway becomes adriving locomotive of the future economy, to increase the competitiveness of the corridors passing through Georgia, along with partner organizations, to create long-term sustainable transportation models, be the effective part of the State Security system the following measures needs to be carried out:

- Diversification of the cargo and regions in order to increase the profitability;

- Increase and develop freight transportation business and use new geographical areas;

- Business focused only on main directions;

- Maintain the competitiveness of the Caucasus Corridor; 
- Creating flexible and efficient structures for both capital and operating expenses.

- Further development and modernization of infrastructure.

Implementation of new standards in Georgian Railway

- To increase the average weight of cargo carriers up to 3,500 tons.

- Add new type locomotives.

- Modernization of central dispatch.

- Introduction of full avtoblocking system.

- Harmonization with EU Directives

\section{References}

Bewick, V., Cheek, L., \& Ball, J. (2003). Statistics review 7: Correlation and regression. Critical Care, 7 , 451-459. https://doi.org/10.1186/cc2401

Binder, T., Cullinan, T., \& Polakovic, L. (2010). Full analysis about Georgian railway. Standart \& Poor's.

Booz Allen Hamilton [BAH]. (2005). Georgian Railways Restructuring Assistance. Assessment Report, May 2005

Bundesnetzagentur. (2018). Railway Market Analysis Germany 2018. Bundesnetzagentur für Elektrizität, Gas, Telekommunikation, Post und Eisenbahnen. Retrieved from https://www.bundesnetzagentur.de/SharedDocs/Downloads/EN/BNetzA/PressSection/ReportsPublications/ 2018/GermanMarketAnalysisRailway2018.pdf?_blob=publicationFile\&v=3\&fbclid=IwAR2OxmdXsGi0y PzzwGhOdjBu87V8n_OLMCbmXSBt_7qqXX2BSpjsxbACRWQ

Diasamidze, T. (2016). Problems of development of maritime transport in Georgia and directions of their solution. Doctoral thesis. Georgian Technical University, Tbilisi, Georgia. Retrieved from http://dspace.nplg.gov.ge/bitstream/1234/173205/2/AVTOREFERAT.pdf

East Japan Railway Company. (2017) Annual report 2017. Pursuing. Retrieved from https://www.jreast.co.jp/e/investor/ar/2017/pdf/ar_2017-all.pdf?fbclid=IwAR0FYmEaGrMuoP7FiW3bFR8 b3nf3JJ8Pzu8y-BO653cDtdj8tGRmj98z1gU

Georgian Railway Information Technology Agency. (2019). The volume of the freight transported by JSC "Georgian Railway" in 2003-2018. Retrieved from http://www.railway.ge/en/

Gondauri, D., \& Moistsrapishvili, M. (2019). Development of Railway Silk Road as a Platform for Promoting Georgia's Economic Growth. International Journal of Business and Management, 14(6), 64-75. https://doi.org/10.5539/ijbm.v14n6p64

Indian Railway. (2012). Railway Statistics. Retrieved from http://122.252.243.98/ZRTI1/statistics.pdf?fbclid=IwAR1Qw24AI15XZgcjdsOLQRT6BhZZivIaFCDEjJG Y6fBW3_eACAapIkhay2A

Japaridze, D. (2012). Management of factors affecting the efficiency of investing - innovative projects of the railway transport and its further improvements. Doctoral thesis, Georgian Technical University, Tbilisi, Georgia. Retrieved from http://gtu.ge/Stmm/Pdf/daviT\%20jafaridze.pdf?fbclid=IwAR0cSiNmt4XXqOssQQ1MAT4cn-zf9hWkzKM _0qWZEMIjc1fIGdta8n-e5YQ

Kurtanidze, A. (2012). Modern Conditions of Transport Management Processes and its Development Perspectives, Doctoral thesis, Georgian Technical University, Tbilisi, Georgia. Retrieved from http://www.nplg.gov.ge/dlibrary/collect/0002/000549/disertacia.pdf?fbclid=IwAR2w-JACoNZyhreJkGcBro

Lashkhi, I., Pataraia, T., Gabrielashvili, G., \& Imnaishvili, A. (2008). Georgian Railway (problems and future prospects). Open Society Georgia Foundation (OSGF), book. Retrieved from https://www.osgf.ge/files/newsletterENG/RAILWAY_Final_ENG_9saox0TNn1.pdf

Nakashidze, N. (2016). Measures to improve marine transport management of Georgia. Doctoral thesis. Georgian Technical University, Tbilisi, Georgia. Retrieved from http://dspace.nplg.gov.ge/bitstream/1234/220878/1/Disertacia.pdf

National statistics office of Georgia. (2019). Gross Domestic Product at current prices by 45 activities. Retrieved from http://www.geostat.ge/index.php?action=page\&p_id=119\&lang=eng 
Office of Rail and Road. (2018). 2017-18 Annual Statistical Release - Rail Finance. Retrieved from https://dataportal.orr.gov.uk/media/1037/rail-finance-statistical-release-2017-18.pdf

Putkaradze, B. (2013). Ways of improvement Batumi port management and efficiency. Doctoral thesis. Georgian Technical University, Tbilisi, Georgia. Retrieved from http://www.nplg.gov.ge/dlibrary/collect/0002/000717/Dis.P.B.pdf

Queensland Rail. (2018). Queensland Rail Annual and Financial Report 2017-2018. Retrieved from https://www.queenslandrail.com.au/about\%20us/Documents/Queensland\%20Rail\%20-\%20Annual\%20and \%20Financial\%20-\%20Report\%20-\%202017-18.pdf?fbclid=IwAR0TNfmv_TajXJ_sUnFScoDXEwdt4-MV BxZI8QNd94jMqfKU6hB0sB4b1qA

Sidamonidze, D. (2018). Georgian Railway as part of the South Caucasian Transport Corridor. Journal of Young Researchers, 7, Tbilisi State Univeristy. Retrieved from http://jyr.tsu.ge/index.php/Hoome/ebaut/ge/3/7

Statistics Canada (1999). Rail in Canada 1997. Retrieved from https://www150.statcan.gc.ca/n1/en/pub/52-216-x/52-216-x1997000-eng.pdf?st=eCS5HBk1

Tarimanashvili, J. (2017). Challenges and Prospects of Transport Corridor Passing through Georgia. Retrieved from https://bpi.ge/saqartveloze-gamavali-satransporto-derefnis-gamowvevebi-da-perspeqtivebi/

Telia, L. (2016). The Development of Railway Transport and the Growth Opportunities of Georgia's Transport system. Doctoral thesis, Georgian Technical University, Tbilisi, 0175, Georgia, July 2016. Retrieved from http://dspace.nplg.gov.ge/bitstream/1234/173437/1/Dissertacia.pdf?fbclid=IwAR2d8QZv2Sr_-xwF9rQcgTc 1AyMH-Py1loHLCJLYPfa8RLoIPBLY01muffo

Tsagareishvili, P., \& Gvenetadze, G. (2008). Prospects for energy drainage and diversification of Caspian oilfields. Journal Business and Management, 3(19). Retrieved from http://aaf.ge/index.php?menu=2\&jurn=19\&rubr=3\&mas=601

Tsagareishvili, P., \& Svanidze, G. (2009). Perspectives for attracting Central Asian cargo through the transport corridor passing through Georgia. Journal of business and management, 2(22). Retrieved from http://aaf.ge/index.php?menu=2\&jurn=22\&rubr=0\&mas $=185$

Tsuladze, Z. (2015). "Iron Silk Road" beyond Russia. Voice of America (VOA), December 14, 2015. Retrieved from https://www.amerikiskhma.com/a/georgia-china-railway/3101954.html

\section{Copyrights}

Copyright for this article is retained by the author(s), with first publication rights granted to the journal.

This is an open-access article distributed under the terms and conditions of the Creative Commons Attribution license (http://creativecommons.org/licenses/by/4.0/). 